\title{
Quality of life in people with chronic hemodialysis: association with sociodemographic, medical-clinical and laboratory variables ${ }^{1}$
}

\author{
Verónica Guerra-Guerrero² \\ Olivia Sanhueza-Alvarado ${ }^{3}$ \\ Mirtha Cáceres-Espina ${ }^{4}$
}

\begin{abstract}
Aim: determine the quality of life for people in chronic hemodialysis and its association with sociodemographic, medical-clinical and laboratory variables. Method: exploratory, descriptive, cross-sectional study with stratified probability sampling. Quality of life was assessed using the KDQOL-36 ${ }^{\mathrm{TM}}$. Data were analyzed using SPSS statistical software. Results: 354 people in chronic hemodialysis had low scores on most dimensions of quality of life, mainly Burden of Disease, Physical and Mental Component. Age, sex, education, income, time on dialysis, etiology of the disease, smoking, hospitalizations, albumin, creatinine and transplants were related. The results reveal multiple factors related to quality of life. Conclusion: there is a need to research on other aspects that permit focusing and optimizing the nursing care for these people.
\end{abstract}

Descriptors: Quality of Life; Hemodialysis; Chronic Renal Failure.

\footnotetext{
1 Paper extrated from Doctoral Dissertation "Factores que influyen significativamente en la adherencia y calidad de vida de las personas en hemodiálisis, considerando su experiencia de vida", presented to Universidad de Concepción, Chile.

2 PhD, Professor, Departamento de Enfermería, Universidad Católica del Maule, Chile.

${ }^{3}$ PhD, Professor, Departamento de Enfermería, Universidad de Concepción, Chile.

${ }_{4}^{4}$ MSc, Professor, Departamento de Enfermería, Universidad Católica del Maule, Chile.
}

Corresponding Author: Verónica Guerra Guerrero

Universidad Católica del Maule. Departamento de Enfermería

Avenida San Miguel n 3605

Talca, Chile

E-mail:vguerra@ucm.cl 


\title{
Qualidade de vida de pessoas em hemodiálise crônica: relação com variáveis sociodemográficas, médico-clínicas e de laboratório
}

Objetivo: determinar a qualidade de vida de pessoas em hemodiálise crônica e sua relação com variáveis sociodemográficas, médico-clínicas e de laboratório. Método: estudo exploratório, descritivo, transacional com amostragem de probabilidade estratificada. Qualidade de vida foi avaliada mediante o instrumento KDQOL-36 ${ }^{\mathrm{TM}}$. Os dados foram analisados com o programa estatístico SPSS. Resultados: 354 pessoas em hemodiálise crônica apresentaram pontuações baixas na maioria das dimensões de qualidade de vida, principalmente carga da doença, componente físico e mental. Foram encontradas associações com idade, sexo, escolaridade, renda, tempo em diálise, etiologia da doença, cigarro, hospitalizações, quantidade de remédios, albumina, creatina e transplantes. Os resultados revelam múltiplos fatores relacionados à qualidade de vida. Conclusão: existe a necessidade de se investigar outros aspectos que permitam enfocar e otimizar o cuidado da enfermagem dirigido a essas pessoas.

Descritores: Qualidade de Vida; Hemodiálise; Insuficiência Renal Crônica.

\section{Calidad de vida de personas en hemodiálisis crónica: relación con variables sociodemográficas, médico-clínicas y de laboratorio}

\begin{abstract}
Objetivo: determinar la calidad de vida de personas en hemodiálisis crónica y su relación con variables sociodemográficas, médico-clínicas y de laboratorio. Método: estudio exploratorio, descriptivo, transaccional con muestreo probabilístico estratificado. Calidad de vida fue evaluada mediante el instrumento KDQOL-36 ${ }^{\mathrm{TM}}$. Los datos fueron analizados con el programa estadístico SPSS. Resultados: 354 personas en hemodiálisis crónica presentaron puntuaciones bajas en la mayoría de las dimensiones de calidad de vida, principalmente Carga de la Enfermedad, Componente Físico y Mental. Edad, sexo, escolaridad, ingresos económicos, tiempo en diálisis, etiología de la enfermedad, cigarrillo, hospitalizaciones, número medicamentos, albúmina, creatinina, trasplantes resultaron relacionados. Los resultados revelan múltiples factores relacionados con la calidad de vida. Conclusión: existe necesidad de investigar otros aspectos que permitan enfocar y optimizar el cuidado de enfermería dirigido a estas personas.
\end{abstract}

Descriptores: Calidad de Vida; Hemodiálisis; Insuficiencia Renal Crónica.

\section{Introduction}

Terminal chronic renal failure (TCRF) is a disease with high prevalence and incidence levels around the world(1-2). In recent decades, the number of patients has significantly increased in Chile as well(3). It is a disease with mortal outcomes in the short or medium term ${ }^{(4)}$ and affects many body structures, which is why it is also associated with a worse quality of life $(\mathrm{Q} O \mathrm{~L})^{(5-6)}$.

Until date, there is no cure, although treatments permit the maintenance and extension of life. Hemodialysis (HD) is the most frequent therapy globally ${ }^{(1,4,7)}$ and in Chile as well(2). The treatment is highly complex, demanding and potentially very restrictive and implies profound lifestyle changes ${ }^{(5)}$. www.eerp.usp.br/rlae
Moreover, it is associated with high social and economic costs for health systems ${ }^{(8)}$. Although dialysis therapy allows people to extend their lives and guarantee their survival(9), it also affects the accomplishment of activities of daily living and, in the long term, patients' quality of life. Moreover, the reduced quality of life has been associated with increased morbidity and mortality risks in this population(6).

The quality of life construct has been largely studied in different illnesses and TCRF because of its characteristics and treatment. It represents a permanent concern for health professionals. In 1994, the World Health Organization defined it as "individuals' perception 
of their position in life in the context of the culture and value systems in which they live and in relation to their goals, expectations, standards and concerns"(10). Recently, it has been studied as one of the main results of renal replacement therapy in distinct groups of people and countries, and as one of the main indicators of health and wellbeing(7-8). Studies and interest in the theme have increased in recent years, in line with the progressive increase in the number of people with TCRF and their extended life. Studies agree that QoL is worse in HD patients than in the general population and even in kidney transplantation patients ${ }^{(6-7,11)}$. Another consensus is that the most deteriorated dimension or area is the physical dimension, underlying the mental dimension(12). Research has also centered on identifying the factors that influence quality of life with a view to the establishment of intervention strategies. Some factors related to QoL are: hemoglobin, albumin, creatinine, hematocrit levels; psychosocial factors like marital status, depression and anxiety; sociodemographic and clinical factors like age, gender, duration of kidney disease and dialysis, and concomitant illnesses ${ }^{(12-13)}$.

It is an actual problem that chronic and terminal illnesses like TCRF affect people's QoL, as these influence different areas of their lives. QoL assessment is an important outcome measure, especially in long-term illnesses like TCRF, and generic and specific instruments can be used for this purpose ${ }^{(8)}$. Studies to identify the QoL of HD patients and its determinant factors are a fundamental aspect to evaluate in this population with a view to effective interventions. That is particularly the case in nursing, which is directly related to this kind of treatment, as health-related quality of life (HRQoL) is often evaluated to determine the effectiveness of healthcare and treatment, as well as resource distribution and health policy development(7).

In spite of the above, in Chile, studies on HRQoL in this population are still incipient. The same is true for its association with socio-demographic, medicalclinical and laboratory variables. The aim in this study is to determine the relation between these variables and quality of life among chronic hemodialysis patients in the Seventh Region of Chile.

\section{Methods}

Exploratory, descriptive and cross-sectional correlation study. Stratified probabilistic sampling was applied in function of the dialysis centers in the total number of TRCF patients under HD, in 11 out of 13 dialysis centers in the Seventh Region of Chile, corresponding to 673 people until August 2010. The following centers participated: Talca (Unidad de diálisis y Trasplante Hospital Regional de Talca: 27 out of 50 participants; Enferdial: 42 out of 83 participants; Hemodiálisis Talca: 47 out of 92 participants; Intermédica Diálisis Talca: 42 out of 82 participants); Linares (Nefrodial Linares: 31 out of 60 participants; Hemodiálisis Linares: 45 out of 86 participants); Curicó (Diálisis Curicó Limitada: 46 out of 83 participants); Constitución (Intermédica Diálisis Constitución: 11 out of 22 participants; Servicios Hospitalarios del Centro: 7 out of 11 participants); Parral (Hemodiálisis Parral: 43 out of 83 participants); and San Javier (Nefrodial San Javier: 13 out of 21 participants). The sample included people over 18 years of age, who attended dialysis sessions thrice a week, submitted to dialysis for at least three months, medically stable, without diagnosed mental or cognitive deterioration and who agreed to participate voluntarily.

Data collection started after ethical evaluation by the School of Medicine at Universidad de Concepción, approval from the Scientific Ethics Committee at Servicio de Salud del Maule and authorization from each dialysis center. All participants were informed about the research, voluntarily signed the Informed Consent term and agreed to participate.

For QoL assessment, the Kidney Disease Quality of Life (KDQOL ${ }^{\mathrm{TM}}$ ) instrument was applied, developed by the Kidney Disease Quality of Life Working Group as a specific self-reported health-related quality of life measure for kidney disease patients undergoing hemodialysis ${ }^{(14)}$. The short version of the $\mathrm{KDQOL}^{\mathrm{TM}}$ was used in this study: the KDQOL-36 ${ }^{\mathrm{TM}}$. This instrument consists of 36 items or questions, divided in two components: one general component, including 12 quality of life questions based on the SF-12 (short version of the SF-36), and a specific 24-question component about the kidney disease. At the same time, each item or question is regrouped in five subscales or dimensions, where the general component groups the SF-12 subscale Physical Functioning (questions 1-12) and SF-12 subscale Mental Functioning (questions 1-12); while the specific component groups the subscales Burden of Kidney Disease (questions 1316), Symptoms and Problems (questions 17-28) and Effects of Kidney Disease on Daily Life (questions 29-36) (15). Item scores range from 0 to 100 , with 0 indicating the worst and 100 the best quality of life. The KDQOL$36^{\mathrm{TM}}$ was validated in a Chilean population ${ }^{(16)}$ and is available in Spanish for public use ${ }^{(17)}$. Sociodemographic, medical-clinical and laboratory data were collected on an individual form, based on the clinical files, dialysis files, nursing registers and database at each center. 
Registers for the three months before data collection were considered. Data were collected through structured interviews, held during the patients' dialysis sessions, between August and November 2010.

Data were ordered, coded and processed electronically. SPSS statistical software, version 15.0 for Windows, was used for data analysis. The authors' worksheet was used to calculate the patients' QoL scores $^{(17)}$. Frequency distribution, central trend and dispersion measures were used for descriptive analysis of the samples. Pearson's correlation coefficient (numerical variables), ANOVA and Student's t-test (categorical variables) were used to establish the relation between the quality of life subscales and sociodemographic, medical-clinical and laboratory variables and to compare means. Statistical significance was set as $p<0.05$. Internal consistency analysis of the KDQOL-36 ${ }^{\mathrm{TM}}$, using Cronbach's alpha, resulted in 0.80 .

\section{Results}

Three of the selected participants refused to participate. The final sample consisted of 354 participants, corresponding to $50.7 \%$ of the total population of chronic hemodialysis patients in the Seventh Region, Chile. Table 1 shows the hemodialysis population's sociodemographic characteristics. The mean age was 58.82 years, and most participants were male $(57.9 \%)$, married $(53.7 \%)$, with a partner $(68.6 \%)$, living with the family (89\%) and in the urban region (69.2\%). On average, patients had 7.84 years of education, the majority declared being religious (91\%), professionally inactive $(77.1 \%)$ and monthly economic revenues of less than 5,000 Chilean pesos (53.1\%), equivalent to less than 200 dollars per month.

Table 1 - Sociodemographic characteristics of hemodialysis population

\begin{tabular}{lcccc}
\hline \multicolumn{1}{c}{ Variable } & $\mathbf{n}$ & Percentage \% & Mean & Max/Min \\
\hline Age (Years) & 354 & 100 & 58.82 & $86 / 19$ \\
Male & 205 & 57.9 & - & - \\
Female & 149 & 42.1 & - & - \\
Single & 74 & 20.9 & - & - \\
Married & 190 & 53.7 & - & - \\
Separated/Divorced & 40 & 11.3 & - & - \\
Widowed & 50 & 14.1 & - & - \\
With partner & 243 & 68.6 & - & - \\
No partner & 111 & 31.4 & - & - \\
Lives alone & 36 & 10.2 & - & - \\
Lives with the family & 315 & 89 & - & - \\
Lives with friends/ & 3 & 0.9 & - & - \\
others & & & & -
\end{tabular}

(continue...)
Table 1 - (continuation)

\begin{tabular}{lcccc}
\hline \multicolumn{1}{c}{ Variable } & $\mathbf{n}$ & Percentage \% & Mean & Max/Min \\
\hline Urban Residence & 245 & 69.2 & - & - \\
Rural Residence & 109 & 30.8 & - & - \\
Years of education & 354 & 100 & 7.84 & $20 / 0$ \\
(Years) & 322 & 91 & - & - \\
Religious & 31 & 8.8 & - & - \\
Not religious & 1 & 0.3 & - & - \\
Other & 71 & 20.1 & - & - \\
Employed & 10 & 2.8 & - & - \\
Unemployed & 273 & 77.1 & - & - \\
Inactive & & & - & - \\
Income (Chilean & 188 & 53.1 & - & - \\
pesos per month) & & 24.7 & - & - \\
$\quad<100,000$ & 97 & 12.1 & - & - \\
$101,000-200,000$ & 43 & 4.5 & - & - \\
$201,000-500,000$ & 16 & 2.8 & - & - \\
$>501,000$ & 10 & & & \\
No income & & & & - \\
\hline
\end{tabular}

Table 2 shows the medical-clinical and laboratory characteristics. The main cause of the kidney disease was unknown and the mean duration of dialysis treatment was 47.62 months. $90.1 \%$ did not smoke and $92.7 \%$ had never received transplantation. The mean duration of each dialysis session was 3.66 hours and mean residual diuresis $477.71 \mathrm{ml}$. 86.4\% had not been hospitalized in the last three months, $54.8 \%$ used diuretics and took an average 8.2 medicines per day. Concerning the laboratory parameters, the mean hematocrit level was $28.33 \%$, Kt/V 1.46 , albumin 4.11 $\mathrm{mg} / \mathrm{dl}$, creatinine $7.72 \mathrm{mg} / \mathrm{dl}$, PTH $414.04 \mathrm{pg} / \mathrm{ml}$, ferritin $392.2 \mathrm{ng} / \mathrm{mL}$, potassium $4.74 \mathrm{mEq} / \mathrm{l}$, ureic nitrogen $57.65 \mathrm{mg} / \mathrm{dl}$, calcium $8.74 \mathrm{md} / \mathrm{d}$ and phosphor 5.13 $\mathrm{mg} / \mathrm{dl}$.

Table 2 - Medical-clinical and laboratory characteristics of hemodialysis population

\begin{tabular}{lcccc}
\hline \multicolumn{1}{c}{ Variable } & $\mathbf{n}$ & Percentage \% & Mean & Max/Min \\
\hline $\begin{array}{l}\text { Etiology kidney disease } \\
\text { Diabetic nephropathy }\end{array}$ & 92 & 26 & - & - \\
$\begin{array}{l}\text { Hypertensive } \\
\text { nephropathy }\end{array}$ & 79 & 22.3 & - & - \\
$\begin{array}{l}\text { Obstructive uropathy/ } \\
\text { glomerulonephritis }\end{array}$ & 22 & 6.2 & - & - \\
$\begin{array}{l}\text { Unknown } \\
\text { Others }\end{array}$ & 105 & 29.7 & - & - \\
$\begin{array}{l}\text { Duration of dialysis } \\
\text { treatment (months) }\end{array}$ & 354 & 15.8 & - & - \\
$\begin{array}{l}\text { Smoking } \\
\text { No smoking }\end{array}$ & 35 & 9.9 & 47.62 & $201 / 3$ \\
Transplantations & 26 & 7.3 & - & - \\
No transplantations & 328 & 92.7 & - & - \\
& & 90.1 & - & - \\
\end{tabular}

(continue...) 
Table 2 - (continuation)

\begin{tabular}{lcccc}
\hline \multicolumn{1}{c}{ Variable } & $\mathbf{n}$ & Percentage $\%$ & Mean & Max/Min \\
\hline Hours of dialysis & 354 & 100 & 3.66 & $4.5 / 2.15$ \\
Residual diuresis $(\mathrm{ml})$ & 354 & 100 & 477.71 & $3.000 / 0$ \\
Hospitalizations & 48 & 13.6 & - & - \\
No hospitalizations & 306 & 86.4 & - & - \\
Use diuretics & 194 & 54.8 & - & - \\
No use of diuretics & 160 & 45.2 & - & - \\
Number of medicines & 354 & 100 & 8.2 & $15 / 2$ \\
Hematocrit (\%) & 354 & 100 & 28.33 & $47.67 / 16.8$ \\
Kt/V & 354 & 100 & 1.46 & $9.07 / 0.74$ \\
Albumin (mg/dl) & 354 & 100 & 4.11 & $5.9 / 2.6$ \\
Creatinine (mg/dl) & 354 & 100 & 7.72 & $15.74 / 1.06$ \\
PTH (pg/ml) & 348 & 98.30 & 414.04 & $2624 / 2.55$ \\
Ferritin (ng/mL) & 308 & 87 & 392.2 & $5034 / 4.29$ \\
Potassium (mEq/l) & 352 & 99.43 & 4.74 & $7.5 / 3.3$ \\
Ureic nitrogen (mg/dl) & 351 & 99.15 & 57.65 & $98.23 / 19.23$ \\
Calcium (mg/dl) & 352 & 99.43 & 8.74 & $11.49 / 4.67$ \\
Phosphor (mg/dl) & 352 & 99.43 & 5.13 & $11.27 / 1.87$ \\
\hline
\end{tabular}

QoL results based on the five KDQOL-36 ${ }^{\mathrm{TM}}$ subscales are displayed in Table 3. The subscales Burden of the Kidney disease (C), SF-12 Physical Functioning (PCS) and SF-12 Mental Functioning (MCS) showed the lowest mean scores 31.88 - 37.63 and 43.49, respectively.
The highest mean scores were found in the Symptoms and Problems (S) and Effects of the Kidney Disease (E) subscales, with 74.61 and 56.92, respectively.

Table 3 - Health-related quality of life scores (KDQOL-36 ${ }^{\mathrm{TM}}$ )

\begin{tabular}{|c|c|c|c|}
\hline $\begin{array}{c}\text { Quality of life } \\
\text { KDQOL-36 }{ }^{\mathrm{TM}} \text { Subscale }\end{array}$ & Mean & Range & $\begin{array}{l}\% \text { people } \\
\text { score } \leq 50\end{array}$ \\
\hline \multicolumn{4}{|l|}{ Specific component } \\
\hline 1. Symptoms and Problems (S) & 74.61 & $12.5-100$ & $11.3 \%$ \\
\hline 2. Effects of the Kidney disease (E) & 56.92 & $0-100$ & $42.4 \%$ \\
\hline $\begin{array}{l}\text { 3. Burden of the Kidney disease } \\
\text { (C) }\end{array}$ & 31.88 & $0-100$ & $76 \%$ \\
\hline \multicolumn{4}{|l|}{ Generic component } \\
\hline $\begin{array}{l}\text { 4. SF-12 Physical Functioning } \\
\text { (PCS) }\end{array}$ & 37.63 & $12.32-64$ & $89 \%$ \\
\hline $\begin{array}{l}\text { 5. SF-12 Mental Functioning } \\
\text { (MCS) }\end{array}$ & 43.49 & $\begin{array}{l}15.8- \\
67.64\end{array}$ & $67.2 \%$ \\
\hline
\end{tabular}

Table 4 shows the correlation between sociodemographic, medical-clinical, laboratory characteristics (numerical variables) and quality of life assessed through the KDQOL-36 ${ }^{\mathrm{TM}}$. A correlation was found between age, years of education, duration of dialysis treatment, hours of dialysis session, residual diuresis, number of drugs, systolic arterial pressure, albumin, creatinine, ferritin and ureic nitrogen $(p \leq 0.005)$.

Table 4 - Correlation between sociodemographic, medical-clinical, laboratory data and KDQOL-36 ${ }^{\mathrm{TM}}$ subscales

\begin{tabular}{|c|c|c|c|c|c|}
\hline \multirow{3}{*}{ Variables } & \multicolumn{5}{|c|}{ KDQOL-36 ${ }^{\mathrm{TM}}$} \\
\hline & $\begin{array}{c}\text { Symptoms and } \\
\text { Problems }\end{array}$ & $\begin{array}{l}\text { Effects of the } \\
\text { Kidney disease }\end{array}$ & $\begin{array}{l}\text { Burden of the } \\
\text { Kidney disease }\end{array}$ & $\begin{array}{c}\text { SF-12 Physical } \\
\text { functioning }\end{array}$ & $\begin{array}{l}\text { SF-12 Mental } \\
\text { functioning }\end{array}$ \\
\hline & $\mathbf{r}$ & $\mathbf{r}$ & $\mathbf{r}$ & $\mathbf{r}$ & $\mathbf{r}$ \\
\hline \multicolumn{6}{|l|}{ Sociodemographic } \\
\hline Age & $-0.224^{*}$ & -0.088 & $-0.156^{*}$ & $-0.203^{*}$ & $-0.118^{*}$ \\
\hline Years of study & $0.285^{*}$ & $0.174^{*}$ & $0.366^{*}$ & $0.196^{*}$ & $0.196^{*}$ \\
\hline \multicolumn{6}{|l|}{ Medical-Clinical } \\
\hline Duration of dialysis & 0.037 & 0.028 & 0.061 & -0.002 & $0.156^{*}$ \\
\hline Hours of dialysis & 0.270 & -0.025 & -0.007 & $-0.128^{*}$ & 0.040 \\
\hline Residual diuresis & $0.140^{*}$ & $0.163^{*}$ & 0.077 & $0.154^{*}$ & 0.053 \\
\hline Number of medicines & -0.014 & -0.007 & 0.043 & $-0.106^{*}$ & 0.092 \\
\hline Systolic arterial pressure & $-0.124^{*}$ & -0.057 & -0.078 & $-0.115^{*}$ & $-0.120^{*}$ \\
\hline \multicolumn{6}{|l|}{ Laboratory } \\
\hline Albumin & 0.073 & 0.057 & $0.115^{*}$ & 0.021 & $0.105^{*}$ \\
\hline Creatinine & $0.109^{*}$ & -0.057 & 0.061 & 0.102 & $0.119^{*}$ \\
\hline Ferritin & $-0.126^{*}$ & -0.045 & -0.019 & -0.053 & -0.009 \\
\hline Ureic Nitrogen & -0.009 & -0.055 & 0.040 & $0.118^{*}$ & 0.008 \\
\hline
\end{tabular}

(r) Pearson's Correlation. * Correlation significant at 0.05 (bilateral).

The relation between sociodemographic, medicalclinical, laboratory characteristics (categorical variables) and health-related quality of life is described in Table 5. Only some QoL subscales were related with sociodemographic characteristics: gender, type o relationship, family situation, residence, occupation, economic revenues, with statistically significant differences in mean values. The medical-clinical characteristics were: etiology of the disease, cigarette smoking, hospitalizations and transplantations. 
Table 5 - Comparison between mean values of sociodemographic, medical-clinical and laboratory data and KDQOL$36^{\mathrm{TM}}$ subscales

\begin{tabular}{|c|c|c|c|c|c|c|}
\hline \multirow[b]{2}{*}{ Sociodemographic variables } & \multicolumn{6}{|c|}{ Mean scores KDQOL-36 ${ }^{\mathrm{TM}}$} \\
\hline & $\mathbf{n}$ & $\begin{array}{l}\text { Symptoms and } \\
\text { Problems }\end{array}$ & $\begin{array}{l}\text { Effects of the } \\
\text { Kidney disease }\end{array}$ & $\begin{array}{l}\text { Burden of the } \\
\text { Kidney disease }\end{array}$ & $\begin{array}{l}\text { SF-12 Physical } \\
\text { functioning }\end{array}$ & $\begin{array}{l}\text { SF-12 Mental } \\
\text { functioning }\end{array}$ \\
\hline \multicolumn{7}{|l|}{ Gender } \\
\hline Men & 205 & $77.19^{\star}$ & $59.87^{*}$ & 33.32 & 38.44 & $44.67^{*}$ \\
\hline Women & 149 & $71.07^{*}$ & $52.87^{*}$ & 29.91 & 36.51 & $41.87^{*}$ \\
\hline \multicolumn{7}{|l|}{ Type relationship } \\
\hline Partner & 243 & $75.93^{*}$ & 55.35 & 30.71 & 37.61 & 43.23 \\
\hline No partner & 111 & $71.73^{*}$ & 60.36 & 34.46 & 37.66 & 44.06 \\
\hline \multicolumn{7}{|l|}{ Family situation } \\
\hline Lives alone & 36 & $68.40^{*}$ & 57.64 & 33.50 & 37.27 & 44.56 \\
\hline Family & 318 & $73.31^{*}$ & 56.67 & 31.44 & 37.67 & 43.45 \\
\hline \multicolumn{7}{|l|}{ Residence } \\
\hline Urban & 245 & 75.14 & 57.67 & $34.48^{*}$ & 37.78 & 44.03 \\
\hline Rural & 109 & 73.43 & 55.25 & $26.03^{*}$ & 37.27 & 42.28 \\
\hline \multicolumn{7}{|l|}{ Occupation } \\
\hline Employed & 71 & $83.95^{*}$ & $63.60^{*}$ & 47.18 & $42.14^{*}$ & $48.14^{*}$ \\
\hline Unemployed & 10 & 12.45 & 45.63 & 32.50 & 41.22 & 40.47 \\
\hline Inactive & 273 & $72.22^{*}$ & $55.60^{*}$ & $27.88^{*}$ & $36.32^{*}$ & $42.39^{*}$ \\
\hline \multicolumn{7}{|l|}{ Income } \\
\hline$\leq 100,000$ & 188 & $71.60^{*}$ & $54.32^{*}$ & $26.46^{*}$ & 36.67 & $41.84^{*}$ \\
\hline$>100,000$ & 156 & $78.05^{\star}$ & $60.13^{*}$ & $38.70^{*}$ & 38.58 & $45.67^{*}$ \\
\hline No income & 10 & 77.29 & 55.62 & 27.50 & 40.67 & 40.48 \\
\hline \multirow{2}{*}{ Medical-clinical variables } & \multicolumn{6}{|c|}{ Mean scores KDQOL-36 ${ }^{\mathrm{TM}}$} \\
\hline & n & $\begin{array}{l}\text { Symptoms and } \\
\text { Problems }\end{array}$ & $\begin{array}{l}\text { Effects of the } \\
\text { Kidney disease }\end{array}$ & $\begin{array}{l}\text { Burden of the } \\
\text { Kidney disease }\end{array}$ & $\begin{array}{l}\text { SF-12 Physical } \\
\text { functioning }\end{array}$ & $\begin{array}{l}\text { SF-12 Mental } \\
\text { functioning }\end{array}$ \\
\hline \multicolumn{7}{|l|}{ Etiology of the disease } \\
\hline Diabetic Nephropathy & 92 & 70.22 & 54.24 & 27.85 & $34.53^{*}$ & 42.05 \\
\hline Hypertensive Nephropathy & 79 & 75.97 & 53.64 & 35.83 & $38.38^{*}$ & 44.11 \\
\hline $\begin{array}{l}\text { Obstructive Uropathy / } \\
\text { Glomerulonephritis }\end{array}$ & 22 & 78.21 & 61.93 & 38.06 & $45.92^{*}$ & 45.20 \\
\hline Unknown & 105 & 75.61 & 59.61 & 30.95 & $37.15^{\star}$ & 43.84 \\
\hline Others & 56 & 74.61 & 58.93 & 32.25 & $39.25^{*}$ & 43.62 \\
\hline \multicolumn{7}{|l|}{ Smoking } \\
\hline Yes & 35 & 78.21 & 59.11 & $41.79^{*}$ & $41.02^{*}$ & 41.41 \\
\hline No & 319 & 74.21 & 56.68 & $30.80^{*}$ & $37.25^{\star}$ & 43.72 \\
\hline \multicolumn{7}{|l|}{ Hospitalizations } \\
\hline Yes & 48 & 72.22 & 52.01 & 31.25 & $34.11^{*}$ & 40.66 \\
\hline No & 306 & 74.99 & 57.69 & 31.99 & $38.18^{*}$ & 43.94 \\
\hline \multicolumn{7}{|l|}{ Transplantations } \\
\hline Yes & 26 & $82.45^{\star}$ & 58.17 & $52.88^{*}$ & $43.67^{*}$ & 47.63 \\
\hline No & 328 & $73.99^{\star}$ & 58.82 & $30.22^{*}$ & $37.14^{*}$ & 43.16 \\
\hline
\end{tabular}

Student's T (t); Bilateral significance (p). Assistential/None (A/N). Fondo Nacional de Salud (F). *p<0.005. Mean values.

\section{Discussion}

Concerning QoL, a high percentage of patients scoring below the reference value of 50 points (scale from 1 to 100 points) was found in three of the five KDQOL-36 ${ }^{\mathrm{TM}}$ subscales. Burden of the disease was the subscale on which participants obtained the lowest mean score, which $76 \%$ scoring below 50 points. The same was true for the Physical and Mental Functioning subscales, as more than $50 \%$ of patients scored less than 50 points on both. As for the Effects of the Disease and Symptoms and Problems subscales, high percentages of participants obtained average scores of more than 50 points: $88.7 \%$ on the Symptoms and Problems subscale 
and $57.6 \%$ on the Effects of the Kidney disease subscale. Many people in the Seventh Region display low scores in all QoL dimensions, in line with other studies(18-19). Scores for Physical Functioning were also lower than for Mental Functioning, in line with other studies ${ }^{(12,18,20)}$. This could reflect people's ability to psychologically adapt to their situation over time, as the time variable reduces the physical aspect of QOL, but not the mental aspect(12).

As for the correlation with numerical variables, a relation was found with age, years of education, duration of dialysis treatment, hours of dialysis, residual dialysis, number of medicines, systolic arterial pressure, albumin, creatinine, ureic nitrogen and ferritin. The following categorical variables were related with QoL: gender, type of relationship, family situation, residence, occupation, social security income, etiology of the disease, smoking, hospitalizations and transplantations.

Men scored better than women on the symptoms, effects and mental functioning subscales. Like in other studies $^{(7,21)}$ describing these differences, women score lower, probably due to the psychological aspect some authors consider determinant in this condition ${ }^{(15)}$. Other studies also describe that this relation does not exist $^{(2,18,22)}$.

With regard to age, a negative correlation was found in all subscales assessed, except in the Effects of the Kidney disease dimension. People over 60 years of age obtained lower QoL scores than people under that age, but only on the symptoms, burden and physical functioning subscales. The latter is a determinant aspect as, according to some authors, QoL is lower in adult people because it is related to greater deterioration in physical exercise ${ }^{(21)}$. The findings differ from ${ }^{(2,13,21)}$ and coincide(11,23) with authors who also describe higher physical and mental functioning scores in younger patients with shorter durations of dialysis treatment, lower education levels and employed. These study results suggest that advanced age is very important in perceived QoL and represents a vulnerable group that needs to be studied in further depth. On the other hand, people with a partner showed better QoL than people without, but only on the symptoms and problems subscale.

People who live alone also scored lower on the symptoms subscale when compared to people who live with other persons. In this study, however, no significant differences were found between people who are married, single, separated or live in any other marital condition, as described in other studies ${ }^{(11,21)}$. Other findings show higher mental functioning scores among people who were married or were living in a relationship like marriage and were employed $^{(12)}$. Authors ${ }^{(21)}$ have indicated living alone as an independent predictor of improvements in the mental health component over time. In this study, the results reveal a better perception of symptom-related QoL among people living with other persons. Living with someone more strongly influences the perceived QoL than people's marital status.

As some authors appoint ${ }^{(21)}$, the disease burden and the limitations its treatment imposes also extend to the caregivers and can significantly influence the perceived QoL. The degree of support received in the family context has also been described as an important predictor of mental QoL ${ }^{(12)}$. It has also been described, however, that the effects of family involvement have not always been beneficial to patients, as these could vary in both senses, between not giving care or exerting too much control on people's lives ${ }^{(2,12)}$.

Concerning the place of residence, people living in rural areas scored lower on the disease burden subscale than people living in urban sectors. No studies were found that evaluate this variable and its relation with the QoL level, but the burden subscale is probably determined by the distances people need to travel from their place of residence, located in rural areas, to the dialysis centers in the city. Transportation times and conditions and, in some situations, the need for a companion can act as negative factors in the perceived QoL. On the other hand, a positive correlation was found between years of education and all subscales. People with more than eight years of education obtained better QoL scores than people with lower education levels. This situation coincides with other authors' descriptions ${ }^{(19)}$ but differ from studies in which no relation was found ${ }^{(13)}$. A positive correlation was also found with the occupation variable. Inactive or unemployed people with low income levels showed an inferior QoL than people who were active or employed or all subscales assessed.

People with a higher income scored higher on the symptoms, burden and mental functioning subscales than people gaining less than 200 dollars per month. Some authors ${ }^{(21)}$ signal that social factors like unemployment, low education level and low purchasing power are associated with a worse QoL, especially when considering social functioning and role limitations due to emotional problems. This is due to the fact that only few people continue working and gaining income that allows them to preserve their earlier condition. Being unemployed contributes to the burden attributed to the kidney disease, especially if the patient is the main 
family provide or family head. The role of work goes beyond the financial level.

For hemodialysis patients, independently of their income, having a job is more important than the money perceived(12). The duration of treatment and hours of dialysis were positively correlated with the mental functioning subscale, and the hours of dialysis were negatively correlated with physical functioning. According to some authors, the duration of treatment can negatively influence QoL. The highest scores were found for people who had spent less time on hemodialysis(12,21-22). In this study, however, people who had spent fewer years on dialysis scored lower on mental functioning than people with more years of treatment. In line with some authors ${ }^{(21)}$, more years of treatment could help to perceive that the QoL improves because people manage to adapt their life to the dialysis and possibly because uremia levels decrease over time, together with the disease symptoms. Residual diuresis was positively correlated with the symptoms, effects and physical functioning subscales. People with a diuresis of more than $1000 \mathrm{ml}$ showed a better QoL than people with a lower residual diuresis. The results coincide with another study ${ }^{(11)}$, where it is considered that a worse residual kidney function can lead to a worse perceived QoL, due to increased awareness about the total dependence on dialysis treatment.

In this study, no association could be identified between concomitant illnesses and QoL level, although it could be established that people whose TCRF was caused by diabetic nephropathy scored lower on the physical functioning subscale than people with other causes. This situation is similar to findings in other studies ${ }^{(11-12,21)}$ that showed a strong relation between associated diseases, especially diabetes mellitus, and worse QoL, although the opposite has also been described ${ }^{(13)}$.

As for smoking, smokers revealed a better QoL than non-smokers on the burden and physical functioning subscales. Similarly, people who had been transplanted at some time in their lives showed better scores than people who had not on four of the five subscales (symptoms/problems, burden, physical and mental functioning).

Differences were also found between people who had not and had been hospitalized in the last three months. Regarding albumin levels, a positive correlation was found with the burden and mental functioning subscales. This positive correlation coincides with other studies ${ }^{(15,21)}$, showing that very low albumin and creatinine levels separately or in combination affect QoL.
Albumin has been described(12,21) as an important factor influencing morbidity, mortality and QoL in hemodialysis patients. High levels have been associated with better QoL levels(20). Serum creatinine levels also showed a positive correlation with the mental functioning subscale. People with creatinine levels superior to $9.41 \mathrm{mg} / \mathrm{dL}$ scored better on the symptoms and mental functioning subscales. Creatinine levels also tend to be associated with a better $\mathrm{QoL}^{(20)}$.

\section{Conclusion}

The sociodemographic profile and medical-clinical and laboratory characteristics of hemodialysis patients in the Seventh Region of Chile contribute to low QoL levels. Higher age, low education, living in rural areas, low income, duration of hemodialysis treatment, hospitalizations and absence of transplantations are some related aspects. Strategies to improve health levels in this population should probably focus on these aspects. This is a quantitative study, which is why its results only center on people's objective aspects. Further research could involve people's subjectivity in order to get a deeper understanding of other QoLrelated aspects, allowing health teams to deliver holistic care to this population.

\section{References}

1. Welch J. Hemodialysis Patient Beliefs by Stage of Fluid Adherence. Res Nurs Health. 2001;24(2):105-12.

2. Cruz M, Andrade C, Urrutia M, Draibe S, NogueiraMartins L, De Castro R. Quality of life in patients with chronic kidney disease. Clinics. 2011;66(6):991-995.

3. Urzúa A, Pavlov R, Cortés R, Pino V. Factores Psicosociales Relacionados con la Calidad de Vida en Salud en Pacientes Hemodializados. Ter Psicol. 2011;29(1):135-40.

4. García F, Fajardo C, Guevara R, González P, Hurtado A. Mala adherencia a la dieta en hemodiálisis: papel de los síntomas ansiosos y depresivos. Nefrología. 2002;22(3):245-52.

5. Denhaerynck K, Manhaeve D, Dobbles F, Garzoni D, Nolte C, De Geest S. Prevalence and Consequences of Nonadherence to Hemodialysis Regimens. Am J Crit Care. 2007;16(3):222-36.

6. Birmelé B, Le Gall A, Sautenet B, Aguerre C, Camus V. Clinical, Sociodemographic, and Psychological Correlates of Health-Related Quality of Life in Chronic Hemodialysis Patients. Psychosomatics. 2012;53(1):30-7.

7. Mendes S, Viana S, Gomes I, De Assis F, Gurgel E, 
Leal M. Factors associated with health-related quality of life in elderly patients on hemodialysis. Rev Saúde Pública. 2011; 45(6):1127-36.

8. Mendes de Abreau M, Walker D, Sesso R, Ferraz

M. Health-Related Quality of Life of Patients Receiving Hemodialysis and Peritoneal Dialysis in Sao Paulo, Brazil: A Longitudinal Study. Value in Health. 2011;14:(S119-S121).

9. García L, Calvanese N. Calidad de vida percibida y locus control en pacientes con tratamiento sustitutivo de la función renal: diálisis y trasplante renal. Anales Univ Metropolitana. 2007;7(1):205-22.

10. Schwartzmann L. Calidad de vida relacionada con la salud: Aspectos conceptuales. Cienc Enferm. 2003;9(2):9-21.

11. Merkus P, Jager K, Dekker F, Boeschoten E, Stevens $P$, Krediet R. Quality of life in patients on chronic dialysis: self-assessment 3 months after the start of treatment. Am J Kidney Dis. 1997;29:584-92.

12. Bohlke M, Leite D, Scaglioni S, Kitamura C, Andrade M, Ost Von-Gysel M. Predictors of quality of life among patients on dialysis in southern Brazil. Sao Paulo Med J. 2008;126(5):252-6.

13. Rebollo P, Bobes J, González M, Saiz P, Ortega F. Factores asociados a la calidad de vida relacionada con la salud (CVRS) de los pacientes en terapia renal sustitutiva (TRS). Nefrología. 2000;20:171-81.

14. Hays RD, Kallich JD, Mapes DL, Coons SJ, Carter WB. Development of the kidney Disease Quality of Life (KDQOLTM) Instrument. Qual Life Res. 1994;3(5):32938.

15. Santos $P$, Franco L. Clinical and laboratory variables associated with quality of life in Brazilian haemodialysis patients: a single-centre study. Rev Med Chile. 2008;136(10):1264-71.

16. Zúñiga C, Dapueto J, Müller H, Kirsten L, Alid R, Ortiz L. Evaluación de la calidad de vida en pacientes en hemodiálisis crónica mediante el cuestionario "Kidney Disease Quality of Life (KDQOL-36)". Rev Med Chile. 2009;137:200-7.

17. KDQOL Working Group [internet].2011. [acesso 20 nov 2011]. Disponivel em: http://gim.med.ucla.edu/ kdqol/

18. Contreras F, Esguerra G, Espinoza J, Gutiérrez C, Fajardo L. Calidad de vida y adhesión al tratamiento en pacientes con insuficiencia renal crónica en tratamiento de hemodiálisis. Univ Psychol. (Bogotá) 2006;5(3):48799.

19. Díaz-Buxo J, Lowrie E, Lew N, Zhang H, Lazarus J. Quality-of-life evaluation using Short Form 36: comparison in hemodialysis and peritoneal dialysis patients. Am J Kidney Dis. 2000;35(2):293-300.

20. Cindoncha M, Estévez I, Marín J, Anduela M, Subyaga G, Diez de Baldeón $S$. Calidad de vida en pacientes en hemodiálisis. Comunicaciones presentadas al XXVIII Congreso Nacional de la Sociedad Española de Enfermería Nefrológica. Comentado en: Univ Psychol. (Bogotá) 2006;5(6):487-99.

21. Morsch C, Goncalves L, Barros E. Health-related quality of life among haemodialysis patients-relationship with clinical indicators, morbidity and mortality. J Clin Nurs. 2006;15(4):498-504.

22. Ismael M, Bernardi C. Qualidade de vida de pessoas com doenca renal cronica em tratamento hemodialítico. Rev. Latino-Am. Enfermagem. 2005;13(5):670-6.

23. Valderrabano F, Jofre R, Lopez-Gomez J. Quality of life in end-stage renal disease patients. Am J Kidney Dis. $2001 ; 38(3): 443-8$. 